\title{
Regional Financial Management Policy that Implies To Criminal Administration
}

\author{
Sugianto Sug \\ sugianto.iain.crb@gmail.com
}

\begin{abstract}
Regional autonomy can not be separated from the issue of the financial capacity of each region. In the previous year, autonomy is always associated with Automoney, it means that the independence of region in organizing its authority can be measured from its ability to explore the sources of income of its own. The Act No. 33 of 2004 is very concerning about the financial balance and accountability between the central government and the region in particular. This study used qualitative method, where data sources are obtained through field observation and literature study. The accountability and regional financial control and procedures for regional goverment budget are very important, because corruption seems to have been pervasive in all aspects of life, including in the government system. The linkage of administrative law with criminal law can be understood because both of them are a public law and in the process of law enforcement, criminal sanctions (criminal law) used to strengthen sanctions in state administrative law. In this case the criminal law is used to enforce the norms in other fields of law, or in other words functionalize the criminal law in the field of law.
\end{abstract}

Keywords: Regional Autonomy, Accountability, Government, Law

\section{Introduction}

The economy and trust crisis that hits Indonesia give positive and negative effect for improving welfare of all Indonesia people. On another hand, the crisis can also give a "blessing in disguise" for improving the living standard of all Indonesia people in the future. Why? Because of the economy and trust crisis that happen has paved the way for emergence of a total reform in all aspects of national life. One element of total reform was the demand of granting broad autonomy to the district and city (Mardiasmo, 2004: 3). In the implementation of regional autonomy as stipulated in Law No. 32 Year 2004 on Regional Government, has been amended by Law No. 8 of 2005 that were previously regulated in Law Number 22 of 1999. It states that granting regional autonomy to regions based on the principle of decentralization in a form of autonomy, real and responsible (Darise, 2009: 1). Speaking about regional autonomy can not be separated from the issue of the financial capacity of each region. Even in the previous year is always associated with Automoney, it means that the independence of region in organizing its authority can be measured from its ability to explore the sources of income of its own. The implication of the application of the principle of Automoney is then pushing regions to increase revenue (Regional Income) vigorously (Sutedi, 2009: 70).

In line with the autonomy of financial management, the government has issued a policy in the form of regulation of the financial sector, namely the enactment of Law No. 17 Year 2003 on State Finance, Law No. 1 of 2004 on State Treasury, Law Number 15 Year 2004 on Management and State Financial accountability, and for the region has been stipulated by Government Regulation No. 58 Year 2005 on regional Financial Management, Government Regulation No. 39 Year 2007 on State Financial Management/Regional Financial Management and Regulation of the Minister of Home Affairs No. 13 of 2006 on Guidelines for Financial Management. Region as guide of its implementation, and since the enactment of these regulations has brought fundamental change in the relationship of governance management as well as bringing the important change in regional financial management (Nugroho, 2007: 14). In Law No. 25 of 1999 (which has been revised to Act No. 33 of 2004) concerning the financial balance between the central government and the region in particular has set the foundation were very clear in the structuring, management and financial accountability region include providing assessment in strengthening product as follows:

a. Provision about products of regional financial management were regulated by regional regulation.

b. System and procedure for regional financial management was regulated by decree of Regional Head in accordance with the regional regulation.

c. Regional Head submits accountability report to Parliament on regional finance terms of efficient and effective finance.

d. The regional financial accountability report is a regional document, so it can be known by the public

(Adisasmita, 2011: 30) 
The definition in the principal point (d) of Law No. 25 of 1999 was a very definite relation with Law No. 15 Year 2004 on Audit of Management and Financial Responsibility of State Article 19; "Reports of the examination results have been submitted to the legislature, in declared open to the public."

\section{Literature Review}

In dissecting research problems along with some understanding of Regional financial management above, there is some sense as a theory to be more clear viewpoint, among others; (1) Theory of Separation and Division of Powers; (2) Theory residue; (3) The theory of Islamic Shari'ah.

Separation Theory and Power-Sharing: This theory was originally born as a result of the king's absolute power in Western Europe. in one aspect, it aims to prevent the growth of power in the hands of one person, whereas in the other aspects, there is no guarantee against to human rights. This teaching by Immanuel Kant called the doctrine of "Trias Politica" Montsquieu. The basic thought of the doctrine of Trias Politica previously had been written by Aristotle and developed by John Locke later. John Locke in his book "Two Treatises on Civil Government", published in 1690, divides the state power into three branches of power, the first, power forms laws (legislative), the second, power implements laws (executive), the third federative power. The executive power according to John Locke, covering power implement or maintain legislation including the judge. Federative power is power that includes all of the powers that are not included in the executive, and legislative branches, which include foreign relation. It was also confirmed by C.F.Strong (Monterquieu first put forward in his book "Esprit des lois", he concluded that if the legislative and executive powers are united in the same person or institution, there will be no independence and dangerous because just like the monarchy or tyranny.

On the same issue, M.Oosterhagen explains "In this respect, the founding fathers resorted to such writers as Lock and Montesquieu, who had both stated that separation of power would provide a safeguard against abuse of power". Further M.Oosterhagen stated" the purpose of the separation of power introduced by Lock is as supervision and restriction of power". According to Bagir Manan, the theory of separation of power in its development, in fact some modern countries rarely apply pure (materially) because besides not practical also negate the surveillance system or the balance between the branches of power and the other one also can emerge tyranny in environment of branches of power each of it. Similar views were also followed by Hans Kelsen, "it is impossible to establish the boundaries that separating these functions from each other, since the difference between establishment and application of the law based on the dualism of legislative and executive power (in the broad sense) and the nature relatively. In Indonesia, The 1945 Constitution embrace and practice the theory of separation of power formally. It proved a connection between all of high state institutions and cooperation in specific areas, as well as the relationship between the Parliament and the President. Both have the power to make laws, set a budget, revenue and expenditure. Relevance and corporation between two state institutions are certainly in a relationship of equality and partnership.

Equality and partnership actually has got a strong grounding in the Preamble of the 1945 Constitution the fourth paragraph, in particular through the principles contained in the precepts of Pancasila (five principles), namely balance, harmony and alignment. The concept or principle popularized relationship "equilibrium" by Sri Sumantri. Relationships are so-called relationship balanced, harmoniously, so there is no mutual domination that often occur in systems of parliamentary or presidential system. Presidential system is identical to how strong the president so it can't be dropped before the term of office ends. While the parliamentary system, the prime minister can be dismissed from office in two ways, first through a noconfidence motion is usually filed by the opposition or the opposition coalition. Secondly, the Prime Minister can be dismissed by a political party outside the agency setting legislative. It means that in a parliamentary system, the legislature is very powerful, it can bring down the executive at any time by reason and specific procedures. Form of power sharing as described above is synonymous with the term dispersal of power horizontally at the same vertical dispersal of power is to bear the central government and the autonomous regions which carry the right of decentralization. Management is a term used in management science

\footnotetext{
${ }^{1}$ Look article 19 Law Number 15 Year 2004 concerning the examination of the State Financial Management and Accountability".
} 
management etymologically derived from the word "manage", and usually refers to the process of taking care of or handle something to achieve the goal.

Residue Theory (Submission Time or Authority): The division of government affairs mandated in Law No. 32 Year 2004 on Regional Government has been reflected in common with the rest of the delivery system of authority or power (reserve of power) in the federal state (Strong, 1952: 100). The system of devolution residual (reserve of power) that adhered as defined in Article 7 paragraph (2), Article 9 of Law No. 32 Year 2004 on Regional Government, that the region tends to interpret raw and assumed all powers beyond the authority of the center is to become the regional authority.

Islamic Sharia Theory: Al-Quran and Sunnah are the two of the four sources of Shari'ah in which the Quran is the first and primary source of Islam is gradually lowered in Arabic, it contains God's revelations tell mankind through Prophet Muhammad PBUH (Peace Be Upon Him). His last Prophet, whereas the Sunnah is a whole deeds and sayings of the Prophet Muhammad. as it is narrated by his companions. In connection with the relationship between people and government, al-Qur'an has set a principle that can be named as the principle of obedience of the people. principle was affirmed in Surah an -Nisa / Chapter 4; Verses 59 which read:

"O you who have believed, obey Allah and obey the Messenger and those in authority among you. And if you disagree over anything, refer it to Allah and the Messenger, if you should believe in Allah and the Last Day. That is the best [way] and best in result".

Hazarin interprets "obey God is to submit to the decrees of God", "obey the apostle" is subject to the messenger's provisions, the Prophet Muhammad PBUH (Peace Be Upon Him) and obey "ulil amri (leader)" is subject to provisions of the officers of power in a task environment of its authority. As for ulil amri provisions in the sense as officials there are two kinds of power namely:

a. Provision which is an election or appointment of the legal line rigorously to be applied to a case or faced case both from the Qur'an and of the Sunnah (Prophet's saying and deeds).

b. Provision which is the establishment of the line of the new law, the new situation according to place and time to be guided by the Qur'an and Sunnah.

The principle of obedience implies that all people, without exception, are obliged to obey the government, scholars of Islamic law agree that the obligation of the people to obey the ruler or the government was implementing democratic principles of Islam, in other words, as long as the ruler or the government does not act unjustly (authoritarian, dictatorial) during which the people shall obey and submit to the authorities. Thus the principle of obedience people alternatively bind people and through this principle also people have the right to correct any errors were committed by the authorities. The core of the people towards the correction of irregularities by the ruling is in the form of a reprimand and advise that the authorities realized his mistake and returned to the decrees of Allah and His Messenger. If the rulers are wrong it has realized his mistake, the people must obey henceforth, on the contrary, if the ruler who mistakenly did not want to realize his error then people are not obliged to obey again and rulers like it should immediately resign or be terminated from his position.

In terms of the principle of obedience can also be interpreted that ruling, unless have the rights of the people obedience to it, he or they are also obliged the interests of the people, the authorities in running its power can not ignore the interests of the public. In a democratic Islam, the ruler shall put the interests of the people rather than personal interests. Thus the obedience of the people against the ruling contains a principle of reciprocity, from an aspect of the people obliged to obey and submit to the authorities, but in terms of other, authorities have to pay attention public interest and implement Islamic democracy principles. According to Rasyid $(2001 ; 211)$ argues that a policy of regional autonomy provide broader autonomy to the government district/city, it is taken in order to restore the dignity of the people in the area by providing opportunities of politic education in order to improve the quality of democracy in the region, increased efficiency of local public services, and the creation of a good governance. Regional autonomy is mandated in the 1945 Constitution and its correlation with Law No. 32 of 2004 that the implementation of regional autonomy oriented towards people's welfare, it can be combined with the concept of Islamic law as the order value in improving the quality of Islamic society in all aspects of life. Islamic Shariah associated normatively 
containing messages norm for all aspects of life that can be a reference or guidelines in realizing the objectives of regional autonomy itself both in the economic, social, as well as the rule of law. This is an opportunity and a challenge for the implementation of Islamic law in the implementation of regional autonomy.

\section{Methodology}

This study uses a qualitative method. The data source is divided into two types of data sources, namely primary and secondar. Primary data is a data obtained directly through observation in the field. Secondary data were obtained through documentation relevant to this study, literature or news. Observations carried out research object namely activities in the election form in Indonesia. While the documentation analysis made to various documents relating to the democracy enforcement in election. Furthermore, the collecting data process in this study be adapted to the research type. The data collected in this study, namely in the form of words, actions, documents, situations, and events that can be observed. The validity data test in this study is done through Triangulation which is a data validity testing technique which is done by checking correctness of the data obtained by researchers in other parties who can be trusted. To maintain the validity of the data or research, efforts that based on the triangulation principles. In this study triangulation conducted to data sources, as well using a variety of supporting reference to prove the data which has been found in research such as: recording, photographs or other documents that support.

\section{Analyses and Discussion}

Decentralization changes the system of financial management have presented the facts of the systemic and structural problems, which is not quite solved by simply attaching the instrumental approach or neoinstitutionalism. But must also be checked paradigm of law and the principles of regional finance. How paradigm laws and principles in the context of local fiscal policy in Indonesia, why it is not quite managed to dismantle the problem structural root? With the analysis of legal texts, will be reviewed motives and conflicts of political and economic paradigms in policy processes in the region, particularly good financial governance, whether in accordance with the paradigm welfare people in the context of constitutional and human rights (Wiratraman, 2006). According to Baldereton (in Adisasmita, 2011: 21) argues that the term of administration is same with management that is moving, organizing, and directing the human effort to utilize materials and facilities effectively to achieve a goal.

The purpose of the Regional Financial Management: Demand on the financial management of the people (public money) well is a prime issue, it should be done by the local government in realizing the goal of good governance (clean government), where good regional financial management is the ability to control the regional financial policy as economical, efficient, transparent and accountable (Suparmoko, 2004: 308). In line with the development of need of the state financial management, it is so important to feel the treasury function in the limited source of government financial management efficiently (Barata, and Bambang, 2005: 9). The basic rules are used as regulatory of regional financial management, described in Article 4 paragraph (1) of Government Regulation No. 58 of 2005; "Regional finance is managed orderly, obedient to laws and regulations, efficient, economical, effective, transparent and accountable with regard to the principle of justice, decency, and benefits to society."

Based on the article above that there is closed connection of local finance with State administrative rules, then logically local finance will recognize legal principles as follows:

- The principle of legality; that every act of the administration in the local financial management should be based on the rule of law;

- The principle must not misuse of power; that every regional financial management officer was not justified in using his power beyond the interests of the government.

\footnotetext{
${ }^{2}$ See Government Regulation No. 58 Year 2005 on Regional Financial Management and its description in 2006, pg.15
} 
- The principle may not take or grab authority; that the regional financial manager is not justified taking or exercise authority other than their authority;

- The principle of equality The right for every resident of the State (the principle of nondiscriminatory); the regional financial management officer must act similarly to those who serve;

- The principle of forceful measures; principle of forceful measures or have sanctions in order to provide structuring tools to the regional finance law; (Djumhana, 2007: 24)

As for the regional financial management became the principal and stipulated in Government Regulation No. 58 Year 2005 Article 3 are as follows: ${ }^{3}$

a. General principles of regional financial management

b. Officials who manage regional finance

c. structureof APED

d. Preparation of RKPD, KUA, PPAS, and RKA-SKPD

e. Preparation and adoption of the budget

f. Implementation and budget changes

g. Structuring financial business area

h. Accountability of the budget

i. Control of the budget deficit and the use of surplus

j. General cash management area

k. Accounts receivable management area

l. Investment management area

$\mathrm{m}$. Asset management areas

n. Management of reserve fund

o. Debt management area

p. Guidance and supervision of financial management

q. Completion loss of area

r. Financial management of Regional Public Service

s. Regulation of financial management.

In the regional financial management has been regulated in Regulation of Ministry of Home Affairs No. 13 of 2006 as a replacement for the Ministry of Home Affairs' Decree No. 29 Year 2002 on Guidelines for Management, Accountability and regional Financial Control and Procedures for regional goverment budget, Implementation of Administration of Regional Finance and preparation of calculation of regional goverment budget. Managing the budget is a detailed list of revenues and expenditures of the State or region which is expected within a specified period. The goals of managing the budget itself, they are:

- The welfare of society; with good budget management will lead to direction of economy improvement, income distribution is right on target so it will create stable economic conditions and leads to the public welfare;

- Opening employment opportunities; the budget is well managed and appropriate budget allocation to vital objects will attract labor, employment opportunities. Because of employment opportunities so there is budget distribution;

- Reducing unemployment; the effectiveness and efficiency of the budget and changes of budget allocations to the optimization of the work force with various forms of expansion of new jobs.

- Community Service; indicator of the success of a government is how people feel well served by obtaining optimal satisfaction level. (Adisasmita, 2011: 35)

According to Halim (2002: 236) budget may be used or function as follows:

a. Guidelines; with this function means the units within the organization carrying out activities based on the budget so it can be avoided waste or misuse of the organization's finances;

b. Coordination tools; to achieve the goals of the effective and efficient organization need division of tasks, clear authority and responsibility among the various units;

\footnotetext{
${ }^{3}$ See Government Regulation No. 58 Year 2005 on Regional Financial Management and its description in 2006, pg.15
} 
c. Controls; budget has been implemented for a certain period should be evaluated, either partially or comprehensively to measure the performance of the organization.

By law, regional financial management is meant to ensure the embodiment of the obligation of regional governments must be done with a number of principles, namely: efficient, effective, transparent, accountable, orderly, fair, proper and obey to the laws and regulations (Article 23 paragraph 2 of Law No. 32 2004). The principles are thus influenced by discourse (text of law) principles of governance, which include: legal certainty, orderly state officials, public interest, transparency, proportionality, professionalism, accountability, efficiency, and effectiveness (Article 20, paragraph 1 of Law No. 32 of 2004). Corruption according to Black (1990) is an act which is done with the intent to provide an advantage that does not comply with the obligations of the official and the rights of other parties, wrongly using his or her character to gain an advantage for himself or for others, along with the obligations and rights of others.

In another sense, corruption can be defined as "behavior does not adhere to the principle", carried out by individuals in the private sector or public officials. And decisions are made based on personal or family relationships, corruption will arise, including conflict of interest and nepotism (Tanzi, 1994). Apart from a wide range of corruption understanding the above, legally, the notion of corruption, both the meaning and the type has been formulated, in Law Number 31 Year 1999 jo. Law No. 20 of 2001 on Corruption Eradication and laws previously, namely Law No. 3 of 1971. Various people assume corruption seems to have been pervasive in all aspects of life, into a system and fused with the running state government, including local government. According to Patrick Glynn, Stephen J. Korbin and Moises Naim, which leads to increase activity of corruption, both real and perceived in some countries, because of the systematic political change, so as to weaken or destroy not only social and political institutions, but also the law (Elliot, 1999: 11).

Law No. 31 of 1999 there was setting type of corruption, namely: Article 2 (1). Article 3, Article 5, Act No. 31 of 1999 ex Article 209 of Criminal Code, Article 6 of Law No. 31 of 1999 ex Article 210 Penal Code, Article 7 of Law No. 31 of 1999 ex Article 387 Criminal Code and Article 388 Penal Code, Article 8 of Law No. 311999 ex Article 415 Penal Code, Article 9 of Law No. 31 of 1999 ex Article 416 Penal Code, Article 10 of Law No. 31 of 1999 ex Article 417 Penal Code, Article 11 of Law No. 31 of 1999 ex Article 418 Penal Code, Article 12 of Law No. 31 of 1999 ex Articles 419, 420, 423, 425, 435 Penal Code, Article 13 of Law No. 31 of 1999, Article 14 of Law No. 31 of 1999, and Article 15 of Law No. 31 of 1999. From this it was obvious that the application of Article 2 and 3 of Law No. 31 of 1999 is easy to prove but contains multiple interpretations, but other chapter is very hard to prove but it is not open to multiple interpretations. The element of "unlawful" (vide Article 2 (1) of Law No. 31 of 1999 jo. Law No. 20 of 2001) and the element of "abusing the authority of opportunity or means available to him because of the position or positions" (vide Article 3 vide Article 2 paragraph (1) of Law No. 31 of 1999 jo. Law No. 20 of 2001) often occurs misconceptions between the two elements.

Definition of "the characteristic against formal law" is often confused with the notion of "misuse of authority" when it is clearly different, because the characteristic against formal law can be committed by any person while abusing the authority can only be done by someone who has the authority and specified capacity in writing by a rules formal (written). It should be understood correctly as it will be related to the problem of collecting evidence and proof in court. In fact, the elements against the law as referred to in Article 2 paragraph (1) of Law No. 31 of 1999 in conjunction with Law No. 20 of 2001 not only against the characteristic in the sense of criminal law, but also include unlawful administration. Thus, errors or violations of administrative law can be adopted into the characteristic against the law as stipulated in the Law on Corruption Eradication, if from an administrative error has caused losses to the state or the country's economy.

In Law No. 32 of 2004 regulates the supervision over the local government, which in practice carried out by the internal regulatory authorities which are embodied in the Regional Supervisory Agency both in the provincial government and district / city. Results of supervision can be used as an inspection by the Financial Audit Board (Article 221 of Law No. 32 Year 2004 on Regional Government). Thus, in law enforcement in the region, especially in the government's efforts to combat corruption, the Inspectorate should be involved in efforts to combat corruption in preventive and administrative perspective. As well as efforts to improve supervision and inspection in the framework of eradication of corrupt practices (corruption, collusion, and 
nepotism), the government and the House of Representatives then passed Law No. 28 of 1999 on Clean State Organizer and Free from Corruption, Collusion, Nepotism. Law No. 28 of 1999 as the basis of legal to establish the State Officials Wealth Audit Commission. Thus, to oversee the wheels of government, there are independent agencies and inspectors and have different tasks, such as ombudsman, State Officials Wealth Audit Commission and Indonesian Supreme Audit Institution (Suhadak, and Nugroho, 2007: 72).

Criminal Sanctions emphasis on Administrative Law: According to Sjachran Wet, in its essence, the state administrative law is the first allows the state administration to carry out their functions and that both protects the citizens against the attitude of the state administration and also acts to protect the state administration itself (Ma'moen, 2001: 281). Meanwhile, the State administration has two (2) meanings, the first in a broad meaning, those are the activities of the legislature, executive and judiciary, and the second in the limited meaning that the activity of the executive agency in implementing government (Mustafa, 2001: 5). Prajudi Atmosudirdjo gives limit of state administrative law as the operational law, it means the law that made and used by officials and state agencies in performing duties, responsibilities and its functions, individually and institutionally. Apart from the above understanding, the field of administrative law covers a very broad scope, not only in the field of tax law or banking alone but all areas of life, including economics and education and so on. Administrative Law is said to be very wide because of administrative law is: "A set of laws were created by an administrative agency in the form of laws, regulations, orders and decisions to run the powers and duties of settings / set of the agency" (Arief, 2003: 13).

The existence of legal sanctions is necessary because the threat of punishment is expected to be achieved through spiritual coercion and influence to educate the stakeholders. One of penalty is a criminal sanction. Administrative Law Enforcement by the criminal law is about sanctions. Importance of criminal sanctions in the enforcement of State Administrative Law by the Criminal Law can be seen from the opinion Logeman quoted Soehardjo Sastrosoehardjo that the State Administration Law that provides the guiding rules in the participating of governments in the association of social economy are the rules that the government penalized in case of violation itself (Ranidajita, 1994: 21). Now, these various legislations include criminal sanctions in the "chapter criminal provisions". With the existence of criminal sanctions in the "chapter criminal provisions" then the law enforcement carried out by the State / Government in this case carried out by the police and the prosecutor. It can be concluded that the government interfere in people's lives with the various tools available to it. One of tool is the criminal law. Criminal law occupied an important role as a medium of government policy. This is because the criminal law has a special position, in the sense of criminal law is not only contained in the legislation of criminal law, but also contained in the various laws and regulations other than the Criminal such as Narcotics Law, Psychotropic Law, Health Law, Education Law, and so on. The development of criminal law is not just in the criminal law itself but has branched out into other areas of law, including in governance. In this case the criminal law is used to enforce the norms in other fields of law, or in other words functionalize the criminal law in the field of law.

In this case, Muladi stated that the involvement of criminal law in the various laws and regulations can be autonomous, in the sense of genuine legislation criminal law itself in formulating acts that are considered to be against the law, in determining the accountability of criminal as well as in the use of criminal sanctions and action needed; and complementary, in the sense of the other fields of law, for example the administrative law. In this kind of position is to support enforcement of criminal law norms that are in other fields of law, for example the setting of tax issues, copyrights, patents and so on. Even in certain cases its role is expected to be more functional than just subsidiary considering the unfavorable economic situation (Muladi, 1990: 148). In the progress there is a change to the function of criminal law, there is development in all life aspects, in developing the welfare society, the criminal law is used as a tool by the government to increase the sense of responsibility of the state / government in order to manage our modern society is more complex. Among other criminal sanctions are used optimally to support the norms of administrative law in various aspects. This is called administrative penal law (Verwaltungs Strafrecht) are included within the framework of public welfare offenses (ordnungswidrigkeiten) (Muladi, 1990: 149). Arief (2003: 42) called criminal law, namely the administration of criminal law in the field of administrative law violations.

The criminal sanction is used if administrative sanctions are not effective, especially with the criminal actor who had gone too far and caused huge losses for example in the field of tax, environment, copyright and 
others (Muladi, 2002: 42). The linkage of administrative law with criminal law can be understood because both of them are a public law and in the process of law enforcement, criminal sanctions (criminal law) used to strengthen sanctions in state administrative law. Administrative law Sanction, according to Spelt and Berge (1993), "sanctions are at the core of the administrative law enforcement. Sanctions are necessary to ensure the enforcement of administrative law". According to De Haan (1986) "in the Administrative Law, the use of administrative sanction is the implementation of governmental authority, which authority is derived from the rules of administrative law, written and unwritten". Oosternbrink (1967) argued "administrative sanctions are penalties that arise from the relationship between the government-citizen and conducted without any third party intermediaries (the judicial power), but can be directly implemented by the administration itself."

\section{Conclusion}

The regional financial management is intended to the embodiment of the obligation of regional governments as the basis of rules that serve regulatory rather than financial management, described in Article 4 paragraph (1) of Government Regulation No. 58 of 2005. The principles are thus influenced by discourse (text of the law ) principles of governance, which include: legal certainty, orderly state officials, public interest, transparency, proportionality, professionalism, accountability, efficiency, and effectiveness (vide Article 20 paragraph 1 of law No. 32 of 2004). Criminal sanctions against the perpetrators or the administration of a person who committed a criminal act of the Government is the right solution.

\section{References}

Abdurrahman, J. (1987). Beberapa Pemikiran Tentang Otonomi Daerah Some Thoughts About Autonomy. Jakarta: Media Means Press.

Adisasmita, R. (2011). Pembiayaan Pembangunan Daerah. Yogyakarta: Graha Ilmu

Agustino, L. (2005). Politik dan Otonomi Politics and Autonomy. Serang: Untirta Press.

Alien, H. J. B. (1985). Enhancing Decentralisation for Developemnt. The Hague: IULA.

APAKSI. (2001). Himpunan Peraturan Pelaksanaan Undang-undang No.22 Tahun 1999 dan Undang-undang No.25 Tahun 1999 The set of Implementing Regulations of Law No. 22 of 1999 and Act 25 of 1999 Jakarta: APAKSI.

Arief, B. N. (2003). Kapita Selekta Hukum Pidana. Bandung: PT Citra Aditya Bakti.

Barata, A. A. \& Bambang, T. (2005). Perbendaharaan dan Pemeriksaan Keuangan Negara/Daerah. Jakarta: PT. Elex Media Komputindo-Gramedia.

Black, H. C. (1990). Black's Law Dictionary. St. Paul Minesota: West Publishing.

Darise, N. (2009). Pengelolaan Keuangan Daerah (Edisi Kedua). Jakarta: PT. Indeks.

De Haan, P. (1986). Bestuursrecht in de Sociale Rechtstaat. Kluwer-Deventer.

Djumhana, M. (2007). Pengantar Hukum Keuangan Daerah dan Himpunan Peraturan Perundang-undangan di Bidang Keuangan Daerah. Bandung: Citra Aditya Bakti.

Elliott, K. A. (1999). Korupsi dan Ekonomi Dunia (Corruption and the Global Economy). Jakarta: Yayasan Obor Indonesia.

Gadjong, A. A. S. (2007). Pemerintahan Daerah Kajian Politik dan Hukum. Bogor: Ghalia Indonesia.

Halim, A. (2002). Akuntansi Sektor Publik akuntansi Keuangan Daerah. Edisi pertama (First Edition). Jakarta: Salemba Empat.

Ma'moen, A. M. (2001). Kedudukan, Tugas dan Wewenang Badan Pertanahan Nasional Ditinjau dari Hukum Administrasi Negara. Yogyakarta: UII Press.

Mardiasmo. (2004). Otonomi dan Manajemen Keuangan Daerah. Yogyakata: Andi.

Muladi. (1990). Proyeksi Hukum Pidana Materiil Indonesia di Masa Datang. Naskah Pidato Pengukuhan Jabatan Guru Besar Dalam Ilmu Hukum pada Fakultas Hukum Universitas Diponegoro. Semarang: UNDIP.

Muladi. (2002). Kapita Selekta Sistem Peradilan Pidana, Cetakan II. Semarang: Badan Penerbit Universitas Diponegoro.

Mustafa, B. (2001). Sistem Hukum Administrasi Negara Indonesia. Bandung: PT Citra Aditya Bakti.

Nasution, A. B. (1999). Federalisme Untuk Indonesia. Jakarta: Kompas.

Nugroho, T. (2007). Paradigma Baru Pengelolaan Keuangan Daerah dalam Penyusunan APBD di Era Otonomi. Malang: Bayumedia. 
Oostenbrink, J. J. (1967). Administratieve sancties - Proefschrift. Gravenhage: Vuga-Boekerij.

Ranidajita, T. H. (1994). Eksistensi Sanksi Pidana Dalam Hukum Administrasi Negara Khususnya Hukum Pajak di Indonesia. Semarang: FH-UNDIP.

Rasyid, R. (2001). Otonomi Daerah Dalam Negara Kesatuan. Yogyakarta: Pustaka Pelajar.

Spelt, N. M. \& Berge, M. T. B. (1993). Pengantar Hukum Perizinan. (Translated in Indonesia by Philipus M. Hadjon). Cetakan Pertama (First Edition). Surabaya: Yuridhika.

Strong, C. F. (1952). Modern political constitutions: an introduction to the comparative study of their history and existing forms. London: Sidgwick \& Jackson Limited.

Suhadak, T. \& Trilaksono N. (2007). Paradigma Baru Pengelolaan Keuangan Daerah dalam Penyusunan APBD di Era Otonomi. Malang: FIA Unibraw and Bayumedia.

Suparmoko, M. (2004). Keuangan Negara dalam Teori dan Praktek. Yogyakarta: BPFE.

Sutedi, A. (2009). Implikasi Hukum Atas Sumber Pembiayaan Daerah dalam Kerangka Otonomi Daerah On the Legal Implications of Regional Funding Sources within the Framework of Regional Autonomy. Jakarta: Sinar Grafika.

Tanzi, V. (1994). Corruption, Governmental Activities, and Markets. IMF Working Paper, August 1994.

Wiratraman, R. H. P. (2006). Kekuasaan Tafsir dan Tafsir Kekuasaan Dalam Hukum The power of interpretations of Power in law. FORUM Keadilan No. 50, April 16, 2006. 